\title{
The Resilience of Kindergarten Teacher in the Disruptive Era
}

\author{
Heldy J. Rogahang, Febri Kurnia Manoppo*, Rolina A.E Kaunang \\ Department of Christian Religious Education \\ Manado State Christian Religion Institute \\ Manado, Indonesia \\ *febri_manoppo@yahoo.com, rolina.ae.kaunang@gmail.com
}

\begin{abstract}
The disruptive era presents many challenges in various fields, including early childhood education. This research aims to discover factors that contribute to resilience of preschool teachers towards the globalization in information era. This study employs a qualitative method to derive the contributing factors on the kindergarten teachers' resilience. The data was gathered through observation, record field notes and interview to six kindergarten teachers in order to get in-depth information related to factors that build their resilience. Data retrieval was guided by using Reivich and Shatte's theory of resilience that underlines the importance of protective factors in overcoming risk factors. The results indicate several factors that positively contribute to the commitment and resilience of kindergarten teachers including the ability of teachers in regulating their emotional, keep focusing on the positive experiences and remain optimistic, and keep boosting their belief that teaching is a calling and be professional teachers. These current findings suggest that personal characteristics contribute on teacher resilience as kindergarten teachers in the disruptive era.
\end{abstract}

Keywords: disruptive era, kindergarten, resilience, teacher

\section{INTRODUCTION}

The world entered an era of disruptive that presents a variety of challenges in various aspects of human life [1]. Era is one of the disruptive impacts of globalization in the information era post truth [2]. This is an age where truth continually questioned, and the reality continues to be reduced back. Negative things that could be the truth without consideration of the rationality of human thought by common sense. In contrast, reality can be considered a negation of the real truth.

In the era of globalization disruptive information makes many changes in various sectors. The education did not escape from it. Terms such as "the world in one hand" further confirms that education did not escape the current global modernization. It requires all parties involved as well as the various stakeholders [3] in education to think extra hard in addressing each impact has been and may occur. This is where we need a variety of considerations and analysis that is both concrete and predictive. Disruptive era also not spared from the impact of the industrial revolution 4.0 makes digitizing information occurs in different places in the world [4].
The world of early childhood education in Indonesia also would not want to feel the impact of digitization of information in the age of 4.0 is that then produces a variety of products that became a kind of challenge for all elements of early childhood education [5], such as teachers, parents, children/learners and other stakeholders. The team conducted observation studies in several places in the province of North Sulawesi. We see the phenomenon that occurs exclusively for kindergarten teachers in the province. Most teachers continue to struggle in various limitations both in terms of human resources, and facilities and infrastructure. Several teachers are still unable to follow the progress of the development of science and technology. Most teachers are trying to teach with trying to fit the capabilities to take advantage of local knowledge and a variety of supporting resources available in their environment at home or school [6]. Teacher also started to do proliferation of courses that offer educational methods from abroad, as well as presenting a fairly competent teachers in the field [7].

Initial observation revealed that the majority of kindergarten teachers in the province of North Sulawesi do not have the certification of competence in the field and paid with less relatively salary to meet their daily needs. However, it was found the high commitment from those teachers in teaching the kindergarten students. The technological advances in the disruptive era has impact also the education in the early childhood education. This study aims to explore factors that contribute to kindergarten teachers' resilience in the disruptive era.

\section{METHODS}

The methodology used to discover factors that contribute teacher resilience in teaching early childhood is a qualitative approach. The data was collected through observation, record field notes and interview to six kindergarten teachers in order to get in-depth information. The participants were focusing in group teachers in Manado, Bitung, and Minahasa province. Data retrieval was guided by using Reivich and Shatte theory of resilience that underlines the importance of protective factors in overcoming risk factors [8]. 


\section{RESULTS AND DISCUSSION}

\section{A. Building a Self-Seated as Professional Teacher}

Being an early childhood teacher is quite challenging since some people perceive the kindergarten teacher as "babysitter". This environment surely affected kindergarten teacher perception on their own profession. The irrelevant education background may also make it worst. It is explored from the interview with a representative teacher was found that she does not have professional certificate as kindergarten teacher. They learned by doing and get enjoyed. They learned that handling early age "students" is not easy. It is required some specific skills to be professional kindergarten teacher. The ability of teacher in regulating their emotion is indispensable since they should handle early childhood from different family background and different characteristics. From the interview, it was discovered that in the beginning, they thought that they could resilience working with early age "students", but then they started to adapt and keep their commitment to be a professional teacher by the time. They manage their own emotion when they are with children to keep children resilience as well. They leave their own problems when they are with children. This effort is in line with resilience theory that underline that good emotion regulation produces positive emotions that can improve the resilience of a person in a situation that full with pressure [8].

\section{B. Seeing the Needs of Children as a Matter of Motivation}

Research about the correlation between job satisfaction and work performance found that salary is one of the magical ways to increase job satisfaction and work performance [9]. However, this current study showed that seeing the needs of early age children to have an education has forced kindergarten teachers to be resilient teacher even they are paid relatively less salary or unpaid for such years. Reivich and Shatte see that impulse control includes a person's ability to see important needs and controlling impulses from within yourself [8]. They keep served to give as best as learning experience for children. Keep optimistic and keep positive thinking make them easier in overcoming the stressful. They tried to create some funs with children they teach. Seeing improvement in the children's behavior helped them in building their confidence and their resilience as kindergarten teachers.

\section{Careness About the Future of The Early Childhood Children They Educate}

This study discovered that empathy is an important thing to be one of the factors of resilience for kindergarten teachers in North Sulawesi. Empathy arising from the teachers is an important factor to love their proteges. Reivich and Shate explain in their theory that empathy is an important part of a person's resilience [8]. A protective factor identified from participant interview is they are happy to be needed and to provide love and care to the children because they realize that children are honest and vulnerable. Their job is to create them to find out their road map in the world. Participants belief that children that they are educating will become the next generation that responsible to build this country someday.
Giving their best service is part of their contribution to better education. They awareness on education has been showed by helping some children that need they help financially as well. Though sometimes people perceived they profession as less valued, but they always try to keep boosting their mind and said to themselves that the work they do is some of the most important work there is. They awareness on early age children education could not always be valued by money.

\section{Call of Life}

The new thing that this current study found about factors that contribute on teacher resilience in North Sulawesi lies is a teacher calling. Teacher calling is a self-seated to teach. Participants remember that the decision to teach is a choice. Though most of them found lack of facilities of the school, but they belief that that situation is one challenging that should be overcome. They said that there is no really perfect place to work, but children deserved their best. Vocation as a teacher is seen as a value that could not be replaced with money. The participants interviewed said that they think that they have been a teacher all their life and teach the children from their heart. They felt satisfied when parents told them how good their child is doing in kindergarten and how teacher helped make that happen.

Disruptive era that sign by technological advances has challenges teacher resilience to be early age teachers. Creativity is an answer that had identified from this current study as protective factors for teacher to be resilient. They explained how creativity helped them to overcome the challenging in disruptive era. The creativity they did is every effort to do many different way to make students become resilience as well in the classroom.

\section{CONCLUCION}

Every one of us human beings have their life calling, whether it's as a lecturer in this regard early childhood teachers, we have no way of each to be able to support the fighting spirit in ourselves that we are familiar with resilience. Resilience early childhood teachers in the Age of disruption has become a strong footing for an early childhood teacher can continue to survive in the world of education and can continue eager to give education to millions of young children are still in need of education.

\section{ACKNOWLEDGMENT}

The author thanks Dr. Jeane Marie Tulung as IAKN Rector in Manado who has supported writers to support and write Thanks to all speakers and for the research team who are also fellow writers of this paper. An extremely valuable compilation for early childhood, for early childhood educators and for all who need this paper. 
[6] M. Windschitl, K. Sahl. Tracing teachers' use of technology in a laptop computer school: The interplay of teacher beliefs, social dynamics, and institutional culture. American educational research journal. 2002 Mar;39(1):165-205.

[1] P.A. Hancock, I. Nourbakhsh, J. Stewart. On the future of transportation in an era of automated and autonomous vehicles. Proceedings of the National Academy of Sciences. 2019 Apr 16;116(16):7684-91.

[2] M.A. Peters. Education in a post-truth world. InPost-Truth, Fake News 2018 (pp. 145-150). Springer, Singapore.

[3] S. Otles and A. Sakalli. "Industry 4.0: The Smart Factory of the Future in Beverage Industry." In Production and Management of Beverages, pp. 439-469. Woodhead Publishing, 2019.

[4] K. Schwab. The fourth industrial revolution. Currency. 2017.

[5] A. Hasan, M. Hyson, M.C. Chang, editors. Early childhood education and development in poor villages of Indonesia: Strong foundations, later success. The World Bank; 2013 Jun 11.

[7] E. Villegas-Reimers. Teacher professional development: an international review of the literature. Paris: International Institute for Educational Planning; 2003 Feb 26.

[8] J.E. Gillham, K.J. Reivich, A.J. Shatté. Building optimism and preventing depressive symptoms in children.

[9] M.T. Al-Zoubi. "The shape of the relationship between salary and job satisfaction: A field study". Far East Journal of Psychology and Business. 2012;7(1):1-2. 